\title{
Labours of Love: Family, Human Rights, and Worker Invisibility in Seasonal Mexican Farm Worker Agricultural Migrations to Canada, 1974-Present ${ }^{1}$
}

\author{
Naomi Alisa Calnitsky
}

"Behind every fruit and vegetable for sale in the supermarket lies an unknown world of toil and skill."2

"I was harvesting squash in the field near my village one day, when my patrón came and said, 'Irena, you should go to Canada. There's now a program there for women.' And I said, 'How can I go to Canada, if I haven't even been to Mexico City?"'3

\section{Introduction}

The Canadian Seasonal Agricultural Worker Program (SAWP) originated in an "offshore program" initiated by the Canadian government in 1966, with the goal of coordinating a seasonal Caribbean labour supply for the province of Ontario. The program grew in significance from the mid-1970s, after being extended to Mexico in 1974. The SAWP's emergence in the latter half of the twentieth century can be read as part of a longer history of managed agricultural migration on the North American continent. In the United States, a bilaterally-coordinated labour scheme was introduced on a large scale with the Mexican Farm Labour Program (MFLP) later known as the Bracero Program-which was initiated in 1942 and ended by the Kennedy Administration in 1964.

This article focuses on a particular strand of Canadian SAWP history to consider how migrant workers were portrayed in the archive, and unpacks early journalistic interviews with Mexican farm workers in Manitoba, which recorded the SAWP's emergence in its early phases. It brings modern-day migrant voices into conversation with an existing academic literature that has, for the most part, highlighted the exploitation inherent to a program in which workers were increasingly rendered invisible and marginal, especially with respect to their full and equal participation in the Canadian economy. While SAWP workers drawn from Mexico chose to participate for diverse reasons - the primary one being economic — oral histories from a field study with farm workers in Manitoba and British Columbia over a three-year period of research (2012-2015) indicate that numerous participants reported positive experiences with the program while many others indicated dissatisfaction owing to a variety of circumstantial, oftentimes localized factors determined by varying experiences of work in Canada. This article includes a consideration of migrant agency in a context of controlled, coordinated motions exercised by both Northern and Southern governments that enabled mobilities, yet constrained the potential for such mobilities to integrate seasonal workers into the 
full and equal fabric of Canadian life.

\section{Methodological Approaches for Defining an Evolving Canada-Mexico Re- lationship}

Following approaches taken by oral historians of farm labour and migration, my own oral history methodology was rooted in an inclusive and culturally sensitive approach that recognized the ways in which different participants might offer unique stories. This had the potential to complicate understandings of the SAWP-its past, and its present. This approach also included discussions and interviews with female workers in a migration climate still dominated by men. I interviewed more than forty Mexican farm workers based in Manitoba and British Columbia-three of whom were women - in addition to one Guatemalan man who migrated to Canada through the parameters of Canada's Temporary Foreign Worker (TFW) program. ${ }^{4}$ Various aspects of migrant experiences were uncovered, from housing conditions to the personal and economic narratives provided by the participants of the study. With oral rather than written consent offered in the field, and pseudonyms used to protect the identities of the SAWP workers involved, my oral histories provided unique windows into the program in a way that could give a more detailed voice to worker experiences not always found in journalistic portrayals. While accounts of working experiences presented in Canadian journalism and documentary film have indeed emphasized the specificities of migrant experiences, most news accounts have offered limited portrayals that focus on one or two workers, rather than presenting a broader range of stories. ${ }^{5}$

Frank Bardacke's revisionist history of the United Farm Workers reread farm labour narratives in a way that refused the victimhood narrative that often dominates literature on farm workers. My own oral history transcripts reflect migrant responses that allow room for positive narratives with the capacity to contest views that centre victimization in the SAWP experience. ${ }^{6}$ The complex social themes addressed in Deborah Cohen's scholarship have included braceros' working and living environments, same-sex dynamics on farms, questions of masculinity, and other interrelated parameters of sexuality. In a similar way, Mireya Loza's work addresses "subthemes" connected to the bracero experience, including the problem of indigeneity. ${ }^{7}$ While Cohen's bracero testimonies provided a Mexico-centred approach linked to bracero memory, emotion, and individualized conceptions of dignity and agency, Loza's extensive contributions to the Bracero History Archive allowed for the increased institutionalization of bracero memory within the sphere of American public history. ${ }^{8}$ Loza's work has paid more attention to the emotional lives of migrants, serving as a model for Canadian social science scholars of migration seeking to archive or represent the voices of contemporary migrant workers; her attention to the politics of compensation associated with ex-braceros also helps to take a historical study into the framework of the present day.

Cohen found that barbershops in Mexico were useful locations to conduct 
oral history interviews, and a similar approach functioned well for my own field research in Manitoba. In my first summer of field research in Manitoba, I met with an Agricultural Workers Alliance representative in Portage la Prairie (that office has since closed), who introduced me to a number of workers employed in the area and pointed out the significant farm sites that were hiring Mexican workers. On visits to Portage, Selkirk, and Winnipeg's Westwood neighbourhood-where workers consistently travelled on Friday evenings-I was able to collect interviews and develop relationships of trust with individual farm workers that could not have been achieved with only one round of fieldwork.

This research operated on a local level and drew from a broader set of studies focused on Mexican transnational migration in a North American context. It was also informed in part by literature on guest work in Europe-in particular the seasonal movements and rhythms of industrial agriculture in key countries like Italy, Greece, and Spain. For instance, international settings like Southern Italy have incorporated North African citrus and tomato harvest workers arriving both legally and illegally via sea to work in Calabrian agriculture. ${ }^{9}$ Such tenuous circumstances have been documented in Canada, where migrants with precarious and temporary work permits have often engaged in farm labour contracts shaped by few legal protections or labour standards.

While groups like Anti-Slavery International have brought the experiences of European migrant harvest workers to light, the research bodies that have been associated with the study of or reporting on seasonal and migrant workers in Canada, including the North-South Institute, Canadian Labour Congress, and the Agricultural Workers Alliance/United Food and Commercial Workers Union (UFCW), have tended not to draw global parallels. Rather, they operate either from a national or hemispheric point of departure, taking Canadian standards as the criterion or benchmark from which to expose their findings. Global migration and its context can serve as a useful frame for locating the mobility of Mexican seasonal workers to Canada since 1974, but it should be stressed that such migrations have engendered their own unique historical outcomes. These have little to do with events occurring elsewhere, despite numerous parallels that might be drawn with other cases of international migration within and across the agricultural sector worldwide.

\section{Writing Seasonal Workers into Canadian History: A Story of "Complemen- tarity"}

Canada's Seasonal Agricultural Worker Program has allowed migrants to cross national boundaries and imprint a unique presence on rural and small-town landscapes. While the term "seasonal worker" risks serving as a euphemism, it is also common currency in official and academic discourses. In a globalized world where natural ecologies and the rhythm of the seasons are increasingly disrupted by global trade flows in both goods and people, the term "seasonal" may require further modifi- 
cation. Despite this, from a historiographical point of view, many borderlands historians and historians of the American West turn to the term "seasonal economies" to denote the ways in which Indigenous peoples' relationships with the land underwent change as settler colonization expanded, and while I use "seasonal" often in this study to describe labour programs as well as workers or individuals, the term should nevertheless not be taken at face value.

In this article, I discuss key themes of interest in the history of temporary farm labour migrations between Mexico and Canada: the role of family and gender; the emergence of women migrants into the program; human rights dimensions of the program as it has evolved; the emergent power positioning of Mexican officials in Canada; and the subjective, "subaltern" stories of workers. I look at themes of exclusion and invisibility, wage and working hour patterns, and the idea of "labour complementarity" in a context of prior competition with First Nations in the agricultural sectors of Ontario and Manitoba. The hiring of women through the parameters of the program began in 1989, and while women have played important roles in a number of industries (including floriculture, tree fruit industries, and food processing), the proportion of women hired in comparison remains small. Thus, the male-dominated nature of the SAWP has often typified its representations, despite the unique attention given to Mexican women's experiences by scholars such as Kerry Preibisch and research studies generated in association with the Canadian Labour Congress. ${ }^{10}$

As Susan Broomhall has recently observed, "the subject of historical emotions is a growing area of interest and one with which many scholars and students are keen to engage."11 I argue that the story of the arrival of Mexican farm workers is one shaped not only by economic and political parameters, but also by a complex emotional and social history marked by the removal of primarily male migrant workers from their communities of origin, and their temporary or seasonal relocation to Canada for lengthy working terms. In this story, I suggest that the Mexican masculine traits of endurance and machismo, combined with a continuing discourse of fatherhood and male breadwinning, often sat uncomfortably alongside new sets of power relations on Canadian farms, greenhouses, nurseries, flower farms, fruit orchards, and vineyards. Adversity, endurance, and separation from spouses and children at home often prevailed as key social characteristics shaping the experiences of SAWP participants. While the structure of my oral history interviews did not emphasize emotion per se, references to children, families, home farms, and occupations in Mexico were at times imbued with pride and were at other times inflected with a sense of hardship or distress.

\section{The Canadian Seasonal Agricultural Worker Program and Its Evolution}

There are numerous references in official discourses and memos concerning the potential arrival of workers from Mexico to the dangers such migrations might pose to Canadian public health. For instance, a 1974 memorandum concerning the 
"Health Screening of Mexican Agricultural Workers" suggested new measures would need to be introduced to test Mexican workers for intestinal parasites such that their "health screening [would] ... comply with Ontario requirements." 12 Anxiety over migrants' health conditions was often linked to notions about protecting Canadians first from any infiltration of disease. The provincial Minister of Health stressed the weight of health screening:

I would appreciate your advising me of arrangements made for health screening procedures for these workers. Health screening is deemed very important as some of this group may be carriers of disease and their occupation will, or may involve food processing or preparation. It is strongly recommended that these workers and other similar groups be permitted entry into Canada only upon compliance with a health screening examination of sufficient quality to detect those conditions which could pose a health risk to residents of this country. It is considered a matter warranting prompt attention in view of the imminence of the current harvest season in parts of this province. ${ }^{13}$

Further correspondence noted that the Mexican government was to be responsible for "selecting only bona fide agricultural workers and ensuring by a medical certificate that each worker is free from any infectious or communicable disease." "This was an early example of bureaucratic anxiety and efforts to maintain a sense of management over incoming farm worker arrivals.

The responsibility for health screening was to be divided between the two nations. A medical examination in the country of origin prior to acceptance in Canada would ensure that workers would arrive in Canada free of any pre-existing health concerns. ${ }^{15}$ Ironically, the Minister of Health failed to predict health problems that resulted specifically from migrants' involvement with Canadian agri-business practices, including the heavy use of agro-chemicals and high incidence of transport-related accidents, which would cause injuries and even fatalities to participant workers. As Jenna Hennebry and Kerry Preibisch have argued, migrants are often baselessly viewed as "potential vectors of disease." ${ }^{16}$ In most cases, migrants' health issues arose after a period of working and living in Canada.

Joy Parr makes the case for the historical emergence of a more hierarchical rural labour system in postwar Ontario, suggesting that scholars

have claimed that from the beginnings of the province, agriculturalists' desire for independence combined with the rigorous seasonality of rural work to determine that "no hierarchical labour organization would persist in Canadian agriculture." Yet in each successive generation from the settlement phase onward, 
rural wage labourers have been essential to the functioning of the province's persistent and unmistakably hierarchical agricultural system. ${ }^{17}$

Parr notes that in 1981, 70,000 wage labourers worked on Ontario farms without protections from unsafe working conditions and without rights under the Labour Relations Act to form unions or gain job security. ${ }^{18}$ She notes that even before Confederation, farm workers in Upper Canada saw wages fluctuate according to the seasons. At the turn of the twentieth century, the numbers of Ontario inhabitants engaged in rural occupations in proportion to those residing in cities steadily declined. Prior to World War II, with increased mechanization, the farm sector became precarious as a source of steady employment for men in Ontario, some of whom resorted to "dovetailing" farm work with other forms of seasonal employment. Most of Ontario's rural workers were "engaged in wage labour because they owned land (or their parents owned land) and they were captivated by the agricultural dream," yet it was the "death of this dream as much as reapers or threshing machines or combine harvesters which would cause them to withdraw their paid labour power from the land."19

With the introduction of the government's "offshore program" in 1966, recruits would soon become structurally crucial and embedded in Ontario's apple, tobacco, and greenhouse sectors as a "quest for reliable labour" came to permeate the program's mandate. ${ }^{20}$ Yet, the rate of deportability associated with the program was often profound. In the program's first year, a religious rift arose between Caribbean Seventh Day Adventist workers and one Canadian employer over the issue of working on Saturdays; the workers were immediately sent home. ${ }^{21}$ In 1973 alone, 140 Caribbean nationals were deported from Canada over the course of their temporary work contracts, for a host of reasons including health, breaching of contracts, and refusal to work. ${ }^{22}$

Significantly, the SAWP's origins stemmed from tobacco and apple cultivation-two industries that required significant manpower at numerous stages. Ontario's tobacco growers initially relied on American migrants, with more than 2,000 arriving in 1958. ${ }^{23}$ Tanya Basok notes that in 1965, there were efforts to incorporate urban Canadians into tobacco fields, but urban-sourced workers were known to abandon work after they were paid and suffered from high rates of alcoholism. ${ }^{24}$ As noted earlier, Canada consented to import West Indian migrants to Ontario to labour in tobacco, apple, and cannery work. Simcoe and York hired "smaller concentrations" of seasonal workers. ${ }^{25}$ In Elgin County, "transients" from Quebec were replaced by "offshore" workers — a group "perceived as steady and dependable." 26

A number of Mexican workers interviewed in Oliver, British Columbia, revealed that they had developed diverse agricultural experiences within the boundaries of the SAWP, meaning that contracts were not often made repetitive or industry-specific for some migrants. One worker outside a gas station in Oliver town 
centre recalled performing tobacco work in Ontario prior to his contract on a vineyard in British Columbia, while his coworker had prior experience harvesting berries outside of Halifax. Others, conversely, had no prior experience of seasonal work in Canada, yet they revealed a great deal of agricultural experience within the boundaries of their own rural lives at home. "Miguel," for instance, was hired as an orchard worker in Oliver after having worked some years in construction labour in Sacramento, California, without any prior experience in Canada. In Sinaloa, Miguel had his own rancho, or large farm, with a horse and some farming implements. In Kelowna, I interviewed "Pedro" at the UBC Okanagan bus interchange; Pedro's employer was a woman and he expressed few complaints about her. At the time of the interview (2012), Pedro had already worked six consecutive years in Canada as a harvest worker and was employed on a cherry and apple orchard among a group of sixty others from Mexico, earning $\$ 9.28$ per hour. He also had two years' prior experience working in strawberries on Prince Edward Island, and eight months in blueberries in Pitt Meadows, BC. He was loading food supplies he had bought in town onto the bus, including Coca-Cola and other groceries. Describing his family situation in Zacatecas, his home town, Pedro spoke of a small ranch where he lived, with cows, as well as five children, three of whom were daughters, the oldest being twenty years old, and the second oldest aged seventeen.

In British Columbia, SAWP workers from Mexico did not arrive until 2004, whereas in Manitoba, Ontario, Quebec, and Nova Scotia, "offshore" hiring from Mexico began in 1974. While concerns and debates about an increased presence of non-citizen guest workers in agricultural Canada have more recently entered public national discourse, migrant agricultural workers from Mexico have occupied a longer and more complex place in Canadian history than most Canadians may approximate.

Linked to this problem of visibility and inclusion is the question of Canadian journalistic treatment of migrant farm workers, and in Manitoba, early oral accounts of farm workers were recorded in a series of news articles printed in the late 1980s and early 1990s. These articles help shed light on family relations, emotion, and the emerging theme of trans-national separation for work and wage-earning opportunities in Canada. In the summer of 1988, some forty men from Mexico were hired in Manitoba, and that year the Winnipeg Free Press sent reporter Maria Bohuslawsky to Mexico to document how the lives of three Mexican families were transformed as a result of the Canadian contracts. Bohuslawsky's described how the "husband-farmworker" would return, "bearing gifts-boxes of clothes, zucchini seeds, pots and pans, a sewing machine, radio, a record player." ${ }^{27}$ Additionally in 1988, corridors of mobility to other seasonal jobs in the US were prevalent among the Manitoba group: Pedro Bello Castro was employed for three years in Manitoba, then followed this contract with a number of years of work in Texas. Bohuslawsky account also revealed Mexican views of Canadian rural landscapes as orderly, in comparison with patterns of disorder at home. According to Sotero Rodriguez 
Dominguez, Portage la Prairie was a "prosperous place with well-organized farms and trusting people," an indication of the diverse and perhaps disorganized rural settings from which many migrants had come. ${ }^{28}$

\section{Farm Labour Competition in the News Archive: Manitoba, ca. 1970s-1980s}

Journalistic accounts reveal the prevalence of cross-cultural antagonisms and competition, but also comradery and friendship, between Indigenous and Mexican workers on Southwestern Manitoba commercial farms. In Manitoba, the housing conditions of itinerant Indigenous farm workers were often degraded. Discrepancies between what were described as "adequate" or even "comfortable" housing units provided for Mexican workers in Manitoba contrasted with "woefully inadequate" living conditions given to Indigenous workers on southern Manitoba sugar beet farms where "shacks and old milk trucks" served as accommodation. ${ }^{29}$ Despite these stark realities, it was the provincial government's view in the mid-1970s that Indigenous workers should predominate as the hired farm workforce in the province. A 1976 farm labour review commissioned by the Government of Manitoba entitled "The Right Thing for the Wrong Reason" advised that imported workforces from Mexico should be "phased out by 1980" and replaced fully with an Indigenous labour force. The review calculated that some 435 First Nations were available to fulfill a demand for 104 full-time and 126 part-time farm workers. ${ }^{30}$

In Avis Mysyk's account of farm work in Manitoba, conflicts between labouring groups of diverse origins prevailed in certain cases:

Despite complaints that Mexicans were taking jobs away from Canadians, "Mexicans and Natives have indicated no hard feelings toward each other this year," said one grower ... The Mexican consul general at the time noted that "Most Mexicans have a lot of very good friends among Indians in Canada. They identify with them as work-mates" ... One Mexican worker admitted that he detected "some bitterness" on the part of local labourers that summer although another said they just ignore it: "We say we don't understand Indian." 31

Patterns of wages and hours of work have also evolved since the early years of the program. In 1983, farm workers "flown in from México" earned $\$ 4.50$ per hour harvesting Manitoba produce with a workday of eight to twelve hours. ${ }^{32}$ One Portage area farmer described how "the Mexicans will put in the extra time that the average Canadian won't. The Mexicans do come here to make money. They're only here for a short period of time." ${ }^{33}$ News also often made reference to wages available in Mexico. In 1983, one farmer at Marquette said his foreign workers

live on the farm and are ready to work at any time. Working by 
a conveyer belt from which he plucked celery stalks to pack with machine-like precision inside cardboard boxes, Teofilo Jimenez said he liked his job at Itzke's farm. "I come to work." ... Jimenez, 33, said he earns about $\$ 10$ a day in México, where he supports a wife and five children. ${ }^{34}$

The same farm would also hire members of the Long Plains Indian Reserve. In 1983, Rose Assiniboine worked at Itzke for eight consecutive years and admitted to having "no quarrel with the Mexican workers. 'I'm just as fast as them." 35

\section{Hearing Migrant Voices: Oral Histories from Manitoba}

In an effort to address the "silences of the archive" through the collection of oral histories, the following two stories provide insights into the complex worlds of Mexican farm labour migrants in Canada. ${ }^{36}$ Owing to the contemporary nature of the migration and the subjects of the study, deeper insights into the SAWP's past were rendered limited through this approach. New insights, however, into the lives of migrants and their worlds were also made possible.

\section{Manuel}

"Manuel" was employed at Connery's vegetable farm in the Portage area. Manuel reported leaving his wife and children in the town of Axtla de Terrazas in the state of San Luis Potosí to work in Manitoba for nine months during the 2013 season. During a Sunday outing in Winnipeg, Manuel found time for a distraction from his regular work routine by strolling the shopping mall to buy clothes and enjoy Chinese food at the cafeteria. In Mexico, he worked mainly in the orange harvest and had by 2013 worked a total of eight seasons in Canada - seven in Manitoba and one in Quebec. Manuel did not have any experience working in the United States. There were also variations in his own past as a farm worker in Manitoba: a previous boss had given many hours of work, yet his current employer did not demand as much labour.

As a temporary agricultural worker in Quebec, he had been employed at a tree nursery. In Manitoba, Manuel's main focus was initially with the asparagus harvest. The job then transitioned to strawberries, and at the time of the interview, Manuel was working the broccoli harvest. Manuel had considered not returning to Manitoba in the coming season, since there was not much work that was nice "no hay mucho trabajo que está bonito" — and he had preferred the work available to him in a past season in Montreal. ${ }^{37}$ This view would shift in mid-October when Manuel set out to return home to his family. At that time, he indicated a hope and expectation to return to Manitoba the next season. He had been afraid of flying before his first trip to Canada but soon lost this fear.

Manuel had been looking forward to returning home since he missed the food, his family, and especially his children. However, Canada still gave him every- 
thing he needed to live better_ " "para vivir mejor" — while Mexico offered him few good economic opportunities. His three sons were in their late teens and early twenties. ${ }^{38}$ Manuel typically arrived in Canada in February, but in 2014 arrived in Manitoba much later-in May-due to a lengthy winter cold spell in the province. ${ }^{39}$ Manuel's account indicates a somewhat ambivalent relationship that many workers have in migrating to Canada, wherein the jobs that were made available often operated imperfectly with their own ideals. If he had described the job as ideal, then his account would fit in with idealized conceptions of the SAWP that have unjustly represented it as the "crème de la crème" of migrant worker schemes, compared to those developed by other host nations worldwide.

\section{Carlos}

The Selkirk-area greenhouse worker "Carlos" was considerably younger than Manuel, and hailed from Hueyapan de Ocampo in the Southern part of the state of Veracruz, not far from the beautiful town of Catemaco. ${ }^{40}$ Carlos noted that the region he was from was highly agricultural and grew a lot of coffee. ${ }^{41}$ In his hometown, he had a small sugar cane field - "tengo terreno de cañas de azúcar" - and he also owned a taxi. ${ }^{42}$ Carlos described his home state of Veracruz as bonito-very nicewith many lakes, beaches, and forests. Ideally, he desired to work another term in Canada in the following year, and enjoyed travelling to Canada for work- " $A$ mi me gusta Canada para trabajar." As for Manitoba, Carlos' impressions of the province were not that favourable. He much preferred his time spent working in Quebec, where he had experience working for six previous seasons. In Quebec, Carlos recalled that there were many more Mexican workers than in Manitoba, and his work involved transporting potatoes from the field to the company storehouse in a big truck: "yo transporte papas del campo a la empresa en un grande camión." During this time, Carlos worked and lived approximately 30 minutes from the city of Montreal, in the town of Joliette.

Carlos enjoyed eating fish and described feeling lucky that Selkirk's river offered good opportunities for fishing. In describing his eating routine, he noted that he did not work on Saturdays or Sundays and so planned to have mole on his next day off as breakfast, and for dinner that night he was preparing carnitas in the shared kitchen in the workers' trailer. While Carlos had never before worked in the United States, preferring not to, he had many family members who lived there, including cousins and uncles in North and South Carolina, Southern California, Las Vegas, Texas, and elsewhere. Interestingly, Carlos indicated that all the women in his family still resided in Mexico while the majority of his family members living abroad in the United States were men. This is another indication of gendered trends in labour emigration within his own family network.

The nuclear family units' temporary loss of integrity posed challenges for guest workers like Carlos, who said: "In Mexico, I am married, but here, I am not," 
indicating the stark new social milieu created for him by labour migration. ${ }^{43}$ By the time August arrived, Carlos was back home in Veracruz. He did, however, anticipate returning to Canada the following year, expecting to work in Ontario. ${ }^{44}$ In April 2015, Carlos informed me of his return to Canada where he had been placed at a floriculture job in Wyoming, Ontario, and accommodated in nearby Sarnia, where it was still "un poco de frio," a little bit cold. ${ }^{45}$ Carlos returned to Veracruz after his work term ended in November.

Despite the daily challenges faced by migrant workers, I found that church outreach workers had made something of a positive impact with farm workers in Lake Country, British Columbia, and among those employed in Manitoba in the Portage la Prairie area. In Winfield, BC, one church provided Spanish-language services for Catholic Mexican farm workers. While the interviews presented above provide only a snapshot into the contemporary experiences of two SAWP farm workers based originally in Manitoba, they reflect a larger body of oral history research from this province. The next section considers two "seasonal lives" in British Columbia, and it should be emphasized that this body of oral history research cannot claim to represent the experiences of all SAWP workers and must be read with this condition and scale in mind.

\section{Shifts in the Harvest Labour Demographic: Oral Histories from the Okana- gan Valley}

British Columbian employers have long relied on young and itinerant workers willing to perform seasonal harvests as well as local British Columbia residents who migrated internally from adjacent regions. Quebec youth still offer peak harvest help in many orchard sectors. However their importance has been dampened by accelerated seasonal migrations from Mexico and the Caribbean, which has flooded the agricultural job market in many high-production regions such as Pitt Meadows, Delta, Ladner, Abbotsford, Mission, Oliver, Osoyoos, Okanagan Falls, Kelowna, Lake Country, Vernon, and Kamloops. In Oliver, La Tienda Mexicana (or, the Mexican shop or store) was a key social site where migrants often gathered. It allowed migrants to recreate their traditional foods and, by extension, cultural niches in Canada. ${ }^{46}$

A field visit to Covert Farms (Fig. 1), north of Oliver, was one of the most beneficial, as I was able to join, meet, and interview a number of the workers on their lunch break after morning work hours on the vineyard. This visit offered a window into the workers' food culture that was mirrored by a different set of field visits made to East Selkirk, Manitoba. An earlier working research trip to the greater Kelowna area found uniquely constructed living quarters built for the seasonal Mexican working group on a cherry and apple orchard estate (Fig. 2). While the onsite trailer housing found on many farms in Manitoba took on a more makeshift character, the housing provided in Kelowna was relatively new and built uniquely to house the SAWP cohort of workers hired there. 
In Lake Country - known as the "Apple Capital of Canada"-increasing numbers of migrant workers have been accommodated in agriculture. The local history of fruit production in this region is intimately bound up with itinerant and internal migration routes, with SAWP workers constituting the latest addition to a longer past shaped by seasonal work and mobility. Mexican migration in the North Okanagan was not, however, limited to Lake Country. It also included sites further north including Vernon, and, in July 2012, recently arrived Mexican workers departed the Kelowna airport to work at Penticton in the South Okanagan and as far north as Kamloops. New nodes of production have thus incorporated seasonal workers into working landscapes that were for decades traditionally reliant solely upon a diverse Canadian backbone.

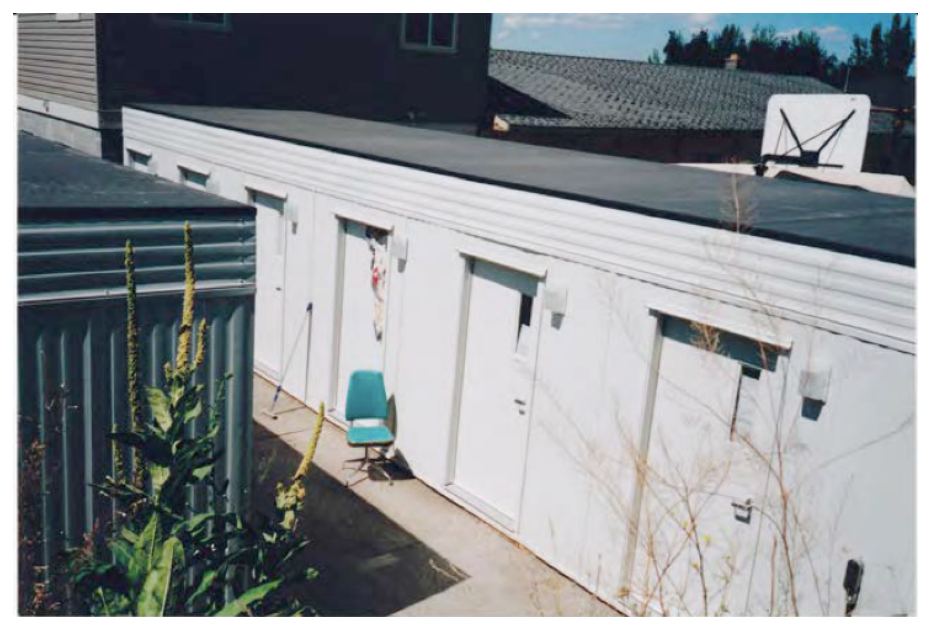

Fig. 1: Mexican SAWP Worker Housing, British Columbia

(Photo Credit: Author, Covert Farms, Oliver, 2012)

\section{Pepe, Orlando, Feliciano, Vicente}

In October 2014, five workers from diverse regions including Veracruz, Oaxaca, Chiapas, and Tabasco gathered outside La Tienda Mexicana on a Friday evening after a day of vineyard work that had begun at five in the morning. One of the workers from Veracruz explained that his region produced a lot of cane sugar-cañas de azúcar. "Pepe," from Oaxaca, was a younger, newer migrant working the grape harvest. He enjoyed his job in Canada, and the money he earned as a temporary worker in British Columbia was much better than that in Mexico. On Friday evenings, he spent his free hours shopping at the nearby supermarket, dollar store, and La Tienda Mexicana. As a vineyard worker, he had one full day off per week on Sundays, when he was able to take a rest. His employer was Canadian and could not converse in Spanish. ${ }^{47}$ 
"Orlando" hailed from Guadalajara, Mexico, and had worked in British Columbia for eight years as a seasonal farm worker. Sporting a T-shirt from Morelia, the capital of Michoacán, Orlando offered a nuanced and opinion-filled account of his current contract and prior experience as a temporary harvest labourer; the work and pay available to him in previous years at a flower nursery in Abbotsford were superior to his most recent vineyard contract that had commenced in April and would end in October. Vineyard pay was not as good as that in floriculture. In Mexico he had five children-three grown daughters and two younger daughters. Orlando expressed interest in locating work in British Columbia that was different from his vineyard job, indicating a sense of dissatisfaction with his current contract. $^{48}$

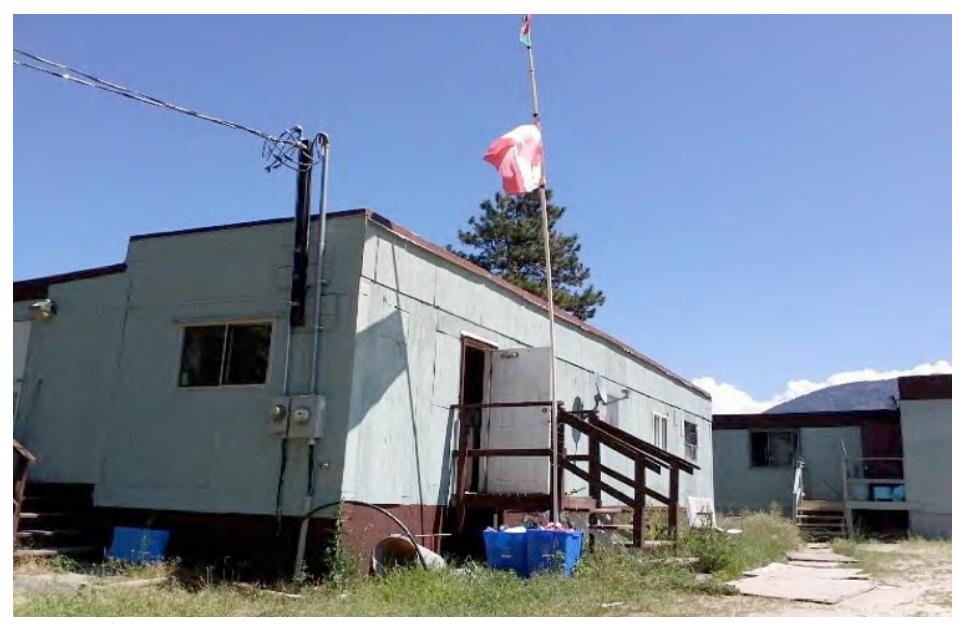

Fig. 2: Mexican SAWP Worker Housing, Greater Kelowna

(Photo Credit: Author, Valley Orchards, Kelowna, 2012)

A second small group of Mexican vineyard workers, on their way to a small local restaurant in Oliver's town centre, was comprised of men from Queretaro, Aguascalientes, and Tlaxcala. "Feliciano," from Tlaxcala, had worked seasonally in Oliver in wine grape harvesting. This was his first season in British Columbia and in Canada. Feliciano was not inexperienced as a migrant farm worker; he had extensive experience working in the United States, including in Miami, North Carolina, South Carolina, and Kentucky. In North Carolina, he was employed in general field labour. According to Feliciano, the work in Canada was okay and the money from vineyard work was good; his pay was much better than what he could earn at home in Tlaxcala. According to Feliciano there were fewer women workers employed in the Oliver area that year, compared with the numbers present in the pre- 
vious year. ${ }^{49}$ "Vicente," from Aguascalientes, explained that once he had gained access to Canada's temporary work program, it was not difficult to "find work" in Canada. The job was coordinated for him, and once recruited, it was easy to work within its parameters, which offered him some measure of stability. ${ }^{50}$

\section{Rights, Unions, and Legal Ambivalence toward SAWP Workers in Canada}

Canadian unionism has dually served as an advocate for migrant farm workers' rights and as a thorn in the side of Canadian employers. The pursuit of migrant freedoms encompassed activism from within, by workers themselves, and activism from without by church workers, unions, and migrant justice organizations in solidarity with the farm worker cause. For instance, in 2011 the Agricultural Workers Alliance (AWA), a branch of the United Food and Commercial Workers (UFCW), highlighted how the Vancouver Mexican Consulate was "giving the workers 'workshops' when they [arrived] to Canada," designed to intimidate and preclude them from creating problems for their employers and to limit their contacts with the wider community; those who stepped beyond such terms in British Columbia faced the prospect of exclusion from the program. ${ }^{51}$ These situations were "seemingly impossible ... to escape." 52

In 2001, Canada's Supreme Court gave temporary agricultural workers the right to join employee associations, while in Ontario their freedom to strike was withheld. The Court's position on foreign farm labour shifted when Dunmore $v$. Ontario revisited agricultural workers' rights. ${ }^{53}$ Judicial wavering has been a hallmark of Canadian reasoning on the rights of foreign farm workers, which continues to rest on ambivalent legal terrain. In Dunmore it was argued that "the distinction between positive and negative state obligations ought to be nuanced in the context of labour relations, in the sense that excluding agricultural workers from a protective regime contributes substantially to the violation of protected freedoms." ${ }^{54}$ In response to the Dunmore verdict, Ontario passed its Agricultural Employees Protection Act (AEPA), weakening the rights of foreign farm workers from their prior status under the Ontario Labour Relations Act. ${ }^{55}$ Since the 2011 Fraser case which concerned farm workers' rights to engage in collective bargaining, the "legal landscape" of section 2(d) specifying freedom of association has lacked clarity and was "fraught with legal uncertainty ... qualified ... by restrictive thresholds." ${ }^{56}$ Foreign farm labour's ambivalent legal status in Canada emerged, I argue, as a result of coded and ambivalent Canadian judicial reasoning on the one hand, and Ontario's specific actions to limit temporary workers' rights to engage in collective bargaining on the other.

Indeed, seasonal labour migrations have resulted in new legal entanglements in Canada. These, alongside persisting racism on many farms, have caused innumerable problems for Canadian courts and for migrant workers. Mexico also emerged as a new violator of Canadian labour codes, as Tom Sandborn observed: 
the government of Mexico, through its Ministry of Labour, violated sections 6(1) and 9 of the provincial labour relations code when it instructed Honorio Corona Martinez ... to initiate a union decertification campaign ... The Mexican government ... threatened Mr. Corona that if he did not advance the decertification campaign, he would not be allowed to return to Canada to work. ${ }^{57}$

In 2010, a total of 40,000 complaints were filed by the storefront-style, UFCW-affiliated workers' alliance centres across Canada. Recent work by Laura Macdonald and Christina Gabriel on the role of what they term "civil society advocacy" in the realm of migrants' rights in Canada has helped complicate the story more recently. It has related to the entrance of Canadian unions into migrant farm worker politics, legal collisions, and the performance of migrant advocacy work in Canada. ${ }^{58}$

In the US Pacific Northwest, the interests of Latin American forestry and farm workers often merged beneficially under the wing of collaborative activism, despite persistent challenges faced by agricultural labour interests and movements in the region. ${ }^{59}$ In Canada, the UFCW performed a similar function for Mexican workers, offering opportunities for representation with moderate but limited success; as Macdonald and Gabriel suggest, the reduced agency of the state as a protector of migrants' interests induced other groups from among civil society to step in to defend migrants' interests. As Brinda Sarathy's work has also shown, the citizen/non-citizen binary developed in particular to describe the experiences of Latin American forestry workers in the United States. This was often inflected by other ambiguities characteristic to the world of labour, including the precarity of certain industries, the deep-seated labour dependencies and asymmetries of power built upon a foundation of ethnonational segmentation, and visa streams that allow in workers without having a built-in regime of labour rights and protections. Indeed, these themes have found many echoes in the history of the SAWP and the associated "Offshore Program" that preceded it. ${ }^{60}$

\section{Conclusions}

Canada's search for orderliness in the complex, tangled, and disorderly world of migration from the South has shaped and defined its position toward agricultural guest workers since 1966. The social history of agricultural migration in postwar Canada might be filtered down to the day-to-day relationships formed on the ground in Canada, yet this story is also inflected by mediating actors participating in processes of recruitment, transit, and management. A study of social factors, including cross-cultural tensions and the boundaries of intimacy across national borders, might help historians of migration better denote the ways in which migrants have endeavoured to carve out worlds for themselves far away from home.

Still, the SAWP was a bureaucratic invention, and however much individual 
workers have successfully struggled to maintain and recreate their worlds, broader structures of collusion and control have still enabled such migrations to occur. The SAWP would develop parameters to define the ideal agricultural migrant according to educational, marital, and rural statuses deemed acceptable by the state. Political considerations have loomed large in defining histories of guest work and have done much to give shape to the movement of seasonal agricultural workers across borders. While Canadian streams for admitting temporary farm workers have undergone shifts and diversification in recent years, my own focus was primarily upon those admitted through the parameters of the SAWP (with one exception). ${ }^{61}$

In Quebec, the hiring of Guatemalan farm workers has provoked much controversy both in terms of the ways migrants have been managed and the ways they have formed a new, highly vulnerable and precarious trans-national agricultural working class. One interviewee, "Modesto," from Guatemala City, ended up in Montreal after four years of seasonal farm work in Quebec in strawberries and greenhouse work. After a period working as an agricultural migrant, Modesto ultimately claimed refugee status and returned to Canada, finding work in construction and gardening. Drawn to Quebec when the temporary agricultural labour program commenced in 2004, Modesto navigated a transnational experience as a migrant wage earner in Canada before forging an independent migration path via refugee status, outside the parameters of farm work. Canadian experiences were for him admittedly superior to life in Guatemala, and his urban Canadian experiences represented an improvement upon his rural Canadian ones, providing him increased independence and control over his personal and daily affairs. Modesto's experience has echoes in American migration patterns where agricultural contracts have consistently paved the way for urban wage-earning opportunities. This dynamic reflects the ways in which the opportunities presented by migration have often been hindered by the perils and challenges built into the transnational migration process, whether it be of a temporary or permanent nature. 


\section{NOTES}

${ }^{1}$ The author would like to thank the anonymous reviewers at Left History for expressing an interest in the material and providing invaluable comments and suggestions for the article's improvement. I would also like to thank the 45 farm worker participants of my 2012-2015 oral history case study in Manitoba and British Columbia, as well as Leslie Macdonald Hicks of the Research Ethics Board for allowing me to adjust my oral history protocols according to the demands of the field. I also thank the Department of History at Carleton University for a Peter Browne Memorial Scholarship for Dissertation Completion. Dr. Patricia Tomic has offered persistent support of my research endeavours, and Michel Hogue kindly agreed to review the dissertation prior to its defence in 2017.

${ }^{2}$ Frank Bardacke, Trampling out the Vintage: César Chávez and the Two Souls of the United Farm Workers (London: Verso, 2011), 30.

${ }^{3}$ Deborah Barndt, Tangled Routes: Women on the Tomato Trail (Boulder, CO: Rowman \& Littlefield, 2001), 192.

${ }^{4}$ See Naomi Alisa Calnitsky, "Harvest Histories: A Social History of Mexican Farm Workers in Canada since 1974," (PhD Diss., Carleton University, 2017).

${ }^{5}$ Two excellent documentaries produced by Min Sook Lee have considered the transnational experiences of SAWP workers. Instances of male migrants experiencing homesickness for their children were evident in Lee's National Film Board work, El Contrato (2003). Her more recent film, Migrant Dreams (2016), continues the earlier film project by highlighting the experiences of migrant workers drawn in from other parts of the world such as Indonesia, and the bonds that can form between them in their working landscape of Leamington, Ontario.

${ }^{6}$ See Bardacke, Trampling out the Vintage.

${ }^{7}$ See Mireya Loza, Defiant Braceros: How Migrant Workers Fought for Racial, Sexual, and Political Freedom (Chapel Hill: University of North Carolina Press, 2016).

${ }^{8}$ See Deborah Cohen, Braceros: Migrant Citizens and Transnational Subjects in the Postwar United States and Mexico (Chapel Hill: University of North Carolina Press, 2011), and The Bracero History Archive, http://braceroarchive.org. This collection includes some five hundred interviews compiled by the Institute of Oral History, University of Texas-El Paso, with the Smithsonian's National Museum of American History. See also Cohen, "From Peasant to Worker: Migration, Masculinity, and the Making of Mexican Workers in the US," International Labor and Working-Class History 69 (2006): 81-103.

${ }^{9}$ See ITUC, Anti-Slavery International, Never Work. Alone: Trade Unions and NGOs joining forces to combat Forced Labour and Trafficking in Europe (Brussels: ITUC, 2011), 30. See also Stephen Castles, "Guestworkers in Europe: A Resurrection?" The In- 
ternational Migration Review 40, no. 4 (2006): 741-767.

${ }^{10}$ See Kerry Preibisch and Evelyn Encalada, Migrant Women Farm Workers in Canada-Information Guide (Guelph: Rural Women Making Change, University of Guelph, July 2008); Canadian Labour Congress, Karl Flecker, "Canada’s Temporary Foreign Worker Program (TFWP): Model Program or Mistake?” (Ottawa: Canadian Labour Congress, 2011).

${ }^{11}$ Susan Broomhall, "Introduction," Early Modern Emotions: An Introduction (London and New York: Routledge, 2017), xxxvi. The Australia-based Society for the History of Emotions (SHE) has in recent years done much to further the establishment of the sub-field.

12 “Mexican Seasonal Workers, 1974," RG76 1208, Immigration Branch, Library and Archives Canada, Ottawa, Canada [hereafter LAC].

13 Ibid.

14 Ibid.

${ }^{15}$ See Janet McLaughlin, "Migration and Health: Implications for development: A case study of Mexican and Jamaican migrants in Canada's Seasonal Agricultural Workers Program," (Ottawa: Canadian Foundation for the Americas, 2009), 4. See also Gerardo Otero and Kerry Preibisch, "The Wild West? Migrants' workplace health and safety conditions in British Columbia horticulture," Annual Meeting of the Canadian Association for Studies in International Development, Vancouver, 2008. McLaughlin's focus on health conditions is unique to the scholarship; see McLaughlin et al., "Paper versus Practice: Occupational Health and Safety Protections and Realities for Temporary Foreign Agricultural Workers in Ontario," Pistes: Interdisciplinary Journal of Work and Health 16, no. 2 (2014): 2-17. ${ }^{16}$ Kerry Preibisch and Jenna Hennebry, "Temporary Migration, Chronic Effects: The Health of International Migrant Workers in Canada," Canadian Medical Association Journal 183, no. 9 (2011): 1034.

${ }^{17}$ Joy Parr, "Hired Men: Ontario Agricultural Wage Labour in Historical Perspective," Labour / Le Travail 15 (1985): 91-92.

${ }^{18}$ Ibid., 92.

${ }^{19}$ Ibid., 96.

${ }^{20}$ Veena Verma, "Remembering and Responsibility," LegalEase C.K.U.T. 90.3

Montreal Radio, November 2011, accessed June 13, 2017, http:/ / archive.org/details/Legalease-Ckut90.3Montreal-Episode27nov2011-RememberingAnd\&reCache $=1$.

${ }^{21}$ Vic Satzewich, Racism and the Incorporation of Foreign Labour: Farm Labour Migration to Canada since 1945 (London: New York: Routledge, 1991), 114.

22 Ibid., 140.

${ }^{23}$ Robert J. Morse, "Seasonal Agricultural Employment in the Flue-cured To- 
bacco Farming Industry of Southern Ontario" (MA thesis, University of Guelph, 1985), 33, microfiche, LAC.

${ }^{24}$ See Tanya Basok, Tortillas and Tomatoes: Transmigrant Mexican Harvesters in Canada (Montreal and Kingston: McGill-Queens University Press, 2002). For more literature on the SAWP from the point of view of sociological fieldwork see Leigh Binford, Tomorrow We're All Going to the Harvest: Temporary Foreign Worker Programs and Neoliberal Political Economy (Austin: University of Texas, 2013). For surveys of US guest worker programs in agriculture involving the Caribbean region as well as Mexico see David Griffith, American Guestworkers: Jamaicans and Mexicans in the U.S. Labor Market (University Park: Pennsylvania State University Press, 2006) and Cindy Hahamovitch, No Man's Land: Jamaican Guestworkers in America and the Global History of Deportable Labor (Princeton: Princeton University Press, 2011).

${ }^{25}$ Morse, "Seasonal Agricultural Employment," 19.

${ }^{26}$ Elgin County Archives, "The Workers," Tobacco in Elgin County, accessed December 15, 2015, http:/ /www.elgincounty.ca/ElginCounty/CulturalServices/ Archives/tobacco/workers.html. For a consideration of the politics of transient tobacco workers in 1930s Ontario see Edward Dunsworth, "Green Gold, Red Threats: Organization and Resistance in Depression-era Ontario Tobacco," Labour/Le Travail 79 (Spring 2017): 105-142. Dunsworth argues that during this period, growers largely acted to protect their own interests (125), spurring on efforts to organize labour beginning in the second part of the 1930s. Hungarians were among the most prominent generators of what Dunsworth terms an "infrastructure of dissent" in the Ontario Tobacco Belt, while other ethnic groups, including Belgians, contributed to the political climate of resistance and labour consciousness in the region. Dunsworth concludes that Tobacco-belt radicalism during the late Depression era in Ontario was of a "fleeting nature" and made only "modest accomplishments," and suggests that Ontario's own history of labour militancy can be informative for Canada's migrant farm labour struggles of the present (140-141).

${ }^{27}$ Maria Bohuslawsky, "Source of Hope: Harvest Work in Manitoba Fields Lets Mexicans Clothe, Feed their Families,” Winnipeg Free Press, June 11, 1988.

28 Ibid.

${ }^{29}$ Avis Mysyk, Manitoba Commercial Market Gardening, 1945-1997: Class, Race and Ethnic Relations (Regina: Canadian Plains Research Centre, University of Regina, 2000), 49.

${ }^{30}$ Ibid., 50-51.

31 Ibid., 51.

32 "Farmers laud willing Mexican labour: Numbers of 'offshore workers' being reduced every year, official says,” Winnipeg Free Press, August 20, 1983, 4. 
${ }^{33}$ Ibid.

34 Ibid.

35 Ibid.

${ }^{36}$ Kristina Llewellyn, Alexander Freund, and Nolan Reilly, The Canadian Oral History Reader (Montreal; Kingston: McGill-Queens University Press, 2015), 9.

${ }^{37}$ Interview with "Manuel,” Portage La Prairie, Manitoba, August 2013.

${ }^{38}$ Interview with "Manuel," Winnipeg, October 17, 2013.

${ }^{39}$ Interview with "Manuel," Winnipeg, June 22, 2014.

${ }^{40}$ Interview with "Carlos," Winnipeg-Veracruz correspondence, Dec. 22, 2015.

${ }^{41}$ Interview with “Carlos,” East Selkirk, Manitoba, June 11, 2014.

${ }^{42}$ Interview with “Carlos,” Winnipeg-Selkirk correspondence, June 22, 2014.

${ }^{43}$ Interview with "Carlos,” East Selkirk, Manitoba, June 2014.

${ }^{44}$ Interview with "Carlos," Winnipeg-Selkirk correspondence, August 12, 2014.

${ }^{45}$ Correspondence with "Carlos," Winnipeg-Sarnia correspondence, April 23, 2015.

${ }^{46}$ There is now an expanding body of literature on food history and Mexican cuisine, intersections between taquerías and urban space, and the integration of regional cuisines into the cuisines of Mexico City. Mexican diasporic cuisine and the arrival of Mexican foods into the United States at the beginning of the twentieth century is another element explored in this literature. See, in particular, Jeffrey Pilcher, Planet Taco: A Global History of Mexican Food (Oxford, New York: Oxford University Press, 2012) and Pilcher, QQue vivan los tamales! Food and the Making of Mexican Identity (Albuquerque: University of New Mexico Press, 1998).

${ }^{47}$ Interview with "Pepe," Oliver, October 10, 2014.

${ }^{48}$ Interview with "Orlando," Oliver, October 10, 2014.

${ }^{49}$ Interview with "Feliciano," Oliver, October 2014.

${ }^{50}$ Interview with "Vicente," Oliver, October 2014.

51 "Join the Community Trial," May 18, 2012, courtesy of AWA Surrey e-correspondence.

${ }^{52}$ Holly Gibbs et al., Negotiating Risk, Seeking Security, Eroding Solidarity (Halifax: Fernwood, 2012), 7.

${ }^{53}$ Paul Cavalluzzo and Adrienne Telford, Freedom of Association, the Right to Bargain Collectively and the Right to Organize (Ottawa: Canadian Foundation for Labour Rights, March 2013), 4; Kirk Makin, "Farm Workers have No Right to Unionize, Top Court Rules," Globe and Mail, April 9, 2001.

${ }^{54}$ Dunmore v. Ontario, [2001] 3 S.C.R 1016, 2001 SCC 94. https:/ / scccsc.lexum.com/scc-csc/scc-csc/en/item/1936/index.do. 
${ }^{55}$ Cavalluzzo and Telford, Freedom of Association, 6.

${ }^{56}$ Ibid., 10.

${ }^{57}$ Tom Sandborn, "Mexican Government Union Busting in BC, Charges Union: Guest Workers pressured by Mexican officials to decertify unions, says UFCW," The Tyee, May 11, 2011. For studies of the SAWP with a focus on its intersections with the Canadian legal landscape, see Robert Marc Russo, "Solidarity Forever, Canadians Never: SAWP Workers in Canada" (PhD diss., University of British Columbia, 2012) and Russo, "Temporarily Unchained: The Drive to Unionize Foreign Seasonal Agricultural Workers in Canada-A Comment on Greenway Farms and UFCW,” BC Studies 169 (Spring 2011): 131-141.

${ }^{58}$ See Laura Macdonald and Christina Gabriel, "Domestic Transnationalism: Legal Advocacy for Mexican Migrant Workers' Rights in Canada," Citizenship Studies 18, nos. 3-4 (June 2014): 243-258, and Macdonald and Gabriel, "Citizenship at the Margins: The Canadian Seasonal Agricultural Worker Program and Civil Society Advocacy," Politics and Policy 39, no. 1 (2011): 45-67. On global migrants' rights movements see Michelle Lowry and Peter Nyers, "Introduction: Global Movements for Refugee and Migrant Rights," in Special Issue of Refuge: Canada's Periodical on Refugees 21, no. 3 (May 2003): 2-4. Lowry and Nyers raise the agency/victimhood debate as it relates to refugees and migrants and their global advocates.

${ }^{59}$ See Lynn Stephen, The Story of PCUN and the Farmworker Movement in Oregon. (Eugene, OR: University of Oregon Center for Latino/a and Latin American Studies, 2012).

${ }^{60}$ See Brinda Sarathy, Pineros: Latino Labor and the Changing Face of Forestry in the Pacific Northwest (Vancouver: University of British Columbia Press, 2011).

${ }^{61}$ By contrast, Canada's Temporary Foreign Worker Program (TFW) led to the "illegalization" of migrants in Canada (some 200,000 in the Toronto area alone) as these vulnerable workers became enmeshed in a race-to-the-bottom labour market. Controlled exit strategies were often limited with the TFW program as it was difficult to enforce deportation when contracts expired. See Charity-Ann Hannan, Harald Bauder, and John Shields, "Towards a Living Wage For All: Illegalized Migrant Workers in Canada and the Role of NGOs in Advocating for their Protection,” Labour Pains, Capital Gains Conference, March 27, 2015. 